\title{
Strategi Pondok Pesantren Al Ma'ruf Kediri Dalam Mencegah Paham Radikalisme Agama
}

\author{
Feri Ferdian, ${ }^{1}$ Bustomi Mustofa, ${ }^{2}$ \\ ${ }_{1,2}$ Institut Agama Islam Tribakti Kediri \\ Ialbanjarif7@gmail.com, ${ }^{2}$ bustomumustofa64@gmail.com
}

\begin{abstract}
The radicalism movement that has taken root in the present must be prevented. Anti-radicalism education can be used as an effort to prevent the development of terrorism and radicalism in Indonesia. The values of anti-religious radicalism in Islam originating from the Qur'an and Hadith are integrated into subjects in Islamic boarding schools. The concept of anti-radical Islam such as prohibiting killing, doing damage, and the command to do love for fellow human beings in the material taught. Anti-radicalism education requires the santri to respect differences. Thus, it can indirectly break the radicalism movement in Indonesia. The research method in this paper uses a qualitative approach, in collecting data using the method of observation, interviews and documents. While the data analysis technique uses editing, verifying and analyzing analysis techniques. The results of this study are the Strategies of Al Ma'ruf Islamic Boarding School in preventing 3 types of religious radicalism, namely: Exemplary Strategy, Coaching Strategy and Habit Strategy.
\end{abstract}

\section{Key Word: Strategy's Pondok Pesantren, Religious Radicalism}

\begin{abstract}
Abstrak
Gerakan radikalisme yang sudah mengakar pada masa sekarang ini harus dicegah. Pendidikan anti radikalisme agama dapat dijadikan upaya pencegahan berkembangnya jaringan terorisme dan radikalisme di Indonesia. Nilai-nilai anti radikalisme agama dalam Islam yang bersumber dari Al-Qur'an dan Hadits diintegrasikan dalam mata pelajaran di pondok pesantren. Konsep Islam yang anti radikal seperti melarang membunuh, berbuat kerusakan, serta perintah untuk berbuat kasih sayang sesama umat manusia dimuat dalam sebuah materi yang diajarkan. Pendidikan anti radikalisme menuntut para santri untuk menghargai perbedaan. Dengan demikian, secara tidak langsung berangsur-angsur dapat memutus gerakan radikalisme di Indonesia. Metode penelitian didalam penelitian ini menggunakan pendekatan kualitatif, dalam pengumpulan data menggunakan metode observasi, wawancara dan dokumen. Sedangkan teknik analisis data menggunakan teknik analisis editing, verifying dan analyzing. Hasil penelitian ini adalah Strategi pondok pesantren Al Ma'ruf dalam mencegah faham radikalisme agama ada 3 macam, yaitu: Strategi Keteladanan, Strategi Pembinaan dan Strategi Pembiasaan.
\end{abstract}

Kata Kunci: Strategi Pondok Pesantren, Radikalisme Agama

\section{Pendahuluan}

Mencegah bahaya radikalisme sebagai akibat dari faham radikalisme tidak dapat hanya diselesaikan dengan proses jalur hukum, akan tetapi juga perlu untuk melibatkan 
dunia pendidikan. ${ }^{1}$ Peran Pondok Pesantren sangat penting dalam mencegah faham radikalisme yang bertentangan dengan syariat agama Islam yang sebenarnya, dengan demikian perlu untuk disadari bahwa betapa pentingnya pemahaman agama Islam dengan jelas kepada para santri, sehingga santri tidak mudah untuk didoktrin oleh paham radikalisme agama. Bahkan dengan tegas bisa dikatakan bahwa radikalisme itu bertentangan dengan kodrat Islam, bahkan secara bahasa sekalipun. Karena secara bahasa Islam memiliki empat makna yang semuanya berkonotasi kepada perdamaian. Maka ketika Islam tidak ditampilkan secara damai, ia akan bertentangan dengan kodrat Islam. ${ }^{2}$ Dasar turunnya agama seolah-olah tidak lagi sesuai dengan yang diharapan, sebab sudah tidak sesuai lagi dengan tujuan agama yakni perdamaian. Oleh karena itu, menjadi seorang Muslim berarti menjadi agen kedamaian dan jika seorang muslim malah berbuat apalagi menyusun strategi-strategi keagamaan dengan kekerasan, maka hal itu bisa difahami bukanlah kemusliman yang diinginkan oleh al-Quran dan Sunnah Rasul SAW. Segala bentuk kekerasan atas nama agama Islam sangat bertentangan dengan semangat damai ajaran Islam. ${ }^{3}$

Fenomena kekerasan atas nama agama yang sering dikenal dengan radikalisme agama semakin tampak garang ketika muncul berbagai peristiwa teror pengeboman di tanah air. Beberapa peristiwa teror dalam bentuk pengeboman telah memakan banyak korban dan berdampak luas terhadap kehidupan sosial masyarakat Indonesia. ${ }^{4}$

Pada tahun 2002, bangsa Indonesia tidak akan pernah lupa dengan tragedi bom Bali I di Paddy's Pub dan Sari Club yang memakan 202 korban jiwa. Hanya berselang tiga tahun kemudian, tragedi bom bali II kembali terjadi di daerah Kuta dan Jimbaran yang menelan 23 korban jiwa. Pelakunya adalah anggota Jamaah Islamiyah (JI) yang memiliki hubungan kuat dengan Al Qaeda, organisasi teroris Internasional di bawah pimpinan Osama bin Laden. Organisasi JI justru tumbuh berkembang di awal zaman era reformasi, dan kemudian kembali melakukan aksi terornya, seperti kasus di Hotel Marriot, Ritz Charlton, Kuningan, dan Serangan Bursa efek Jakarta. ${ }^{5}$

Dua organisasi keagamaan terbesar di Indonesia yakni Nahdlatul Ulama (NU) dan Muhammadiyah telah mengecam terorisme sebagai akibat dari faham radikalisme agama. ${ }^{6}$ Meski demikian, respon itu tidak hanya terhenti pada pernyataan sikap. Diperlukan tindakan lanjut dan nyata dalam mengambil langkah-langkah strategis untuk memperkecil ruang gerak kelompok-kelompok radikalis dengan memberi pendidikan sebaik-baiknya kepada masyarakat khususnya para santri di Pondok Pesantren.

Dalam mendakwah, tujuan mereka menawarkan ideologi dengan menggunakan cara kekerasan dan menampilkan aksi-aksi yang dapat merugikan banyak orang. Selain itu, mereka juga menggunakan cara yang halus bahkan hampir tidak kelihatan dan tanpa

\footnotetext{
${ }^{1}$ Agus SB. Merintis Jalan Mencegaah Terorisme (Jakarta: Semarak lautan Warna Press, 2014), h. 136.

${ }^{2}$ Forum Kajian Ilmiah AFKAR, Kritik Ideologi Radikal: Deradikalisme Doktrin Keagamaan Ekstrem Dalam Upaya Meneguhkan Islam Berwawasan Kebangsaan (Lirboyo Press, 2018), h. 5. h. 53 .

${ }^{3}$ Roni Ismail, "Islam Dan Damai (Kajian Atas Pluralisme Agama Dalam Islam), Jurnal Religi, Vol. 9, No. 1, (Januari, 2013),

${ }^{4}$ Abdul Munip, “(Menangkal Radikalisme Agama di Sekolah)”, Jurnal Pendidikan Islam, Vol. I, No. 2 (Desember, 2012$)$, h.

${ }^{5}$ Muhammad A.S. Hikam, Deradikalisme: Peran Masyarakat Sipil Indonesia Membendung Radikalisme(Jakarta: Kompas, 2016) h. 31-32.

${ }^{6}$ Misrawi Zuhairi, Pandangan Muslim Moderat: Toleransi, Terorisme, dan Oase Perdamaian (Jakarta: PT. Kompas Media Nusantara, 2010), h. 90.
}

Tribakti: Jurnal Pemikiran Keislaman

Volume 30, Nomor 2, Juli 2019 
kita sadari, yaitu dengan cara masuk kedalam lembaga-lembaga pendidikan, baik lembaga formal maupun non formal. ${ }^{7}$

Selain ideologi, kelompok radikalisme juga tidak lepas dari keyakinan berjihad, bisa jadi menurut kelompok radikal jihad adalah satu-satunya cara untuk dapat meyakini orang agar dapat didoktrin untuk menjadi bagian dari mereka. ${ }^{8}$ Setelah itu diperintahkan untuk mengorbankan diri dengan cara apapun, salah satunya bom bunuh diri. Padahal Allah SWT melarang keras untuk melakukan bunuh diri, seperti firman Allah SWT yang berbunyi:

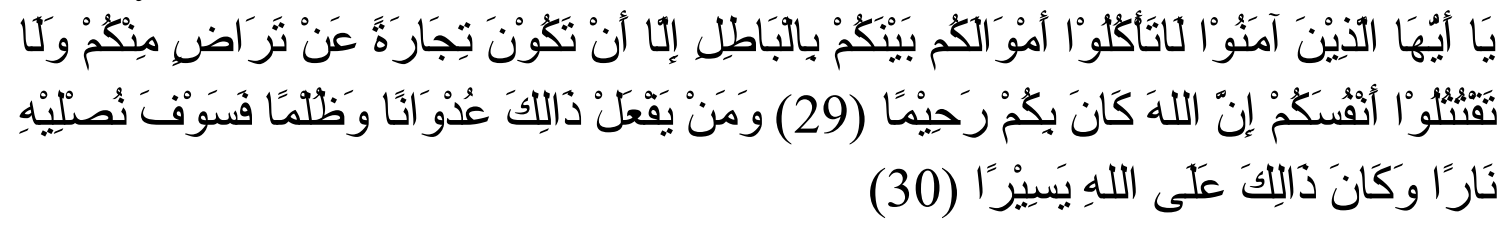

Terjemahnya: Hai orang-orang yang beriman, janganlah kamu saling memakan harta sesamamu dengan jalan yang batil, kecuali dengan jalan perniagaan yang berlaku dengan suka sama suka diantara kamu. Dan janganlah kamu membunuh dirimu, sesungguhnya Allah adalah maha penyayang kepadamu. Dan barangsiapa berbuat demikian dengan melanggar hak dan aniaya, maka kelak akan dimasukkan ke dalam neraka, yang demikian itu adalah mudah bagi Allah. ${ }^{9}$

Dari fenomena tersebut, maka penting untuk mengkaji bagaimana Strategi yang dilaksanakan Pondok Pesantren Al Ma'ruf dalam mencegah faham radikalisme agama". Pondok Pesantren Al Ma'ruf adalah salah satu dari beberapa pesantren yang ada di Kediri yang selalu mengaktifkan kegiatan keagamaan. Di lingkungan pesantren juga tidak terjadi kekerasan yang mengatasnamakan agama Islam yang berawal dari pemahaman yang keliru. Kondisi ini tentu harus selalu dipertahankan oleh pondok pesantren mengingat penyebaran faham ekstrem yang selalu dilakukan dengan berbagai cara. Maka dari itu peran dari pondok pesantren sangat penting dalam mencegah faham radikalisme agama.

\section{Metode Penelitian}

Penelitian ini menggunakan jenis penelitian kualitatif, hal ini dikarenakan akan lebih memusatkan pada keingin-tahuan tentang strategi pondok pesantren dalam mencegah faham radikalisme agama. Adapun pendekatan yang digunakan adalah pendekatan fenomenologis, yaitu pendekatan yang berpendapat bahwa kebenaran sesuatu diperoleh dengan cara menangkap fenomena dari objek yang diteliti.

Dalam pengumpulan data dilapangan dalam sebuah penelitian tentu banyak cara yang dapat digunakan agar masing-masing metode tersebut dapat saling melengkapi dan menyempurnakan, maka dalam pengumpulan data penelitian ini peneliti menggunakan metode observasi, wawancara, dan dokumentasi.

\footnotetext{
${ }^{7}$ Abu Rokhmad, "Radikalisme Islam dan Upaya Deradikalisme Paham Radikal”, Jurnal Kependidikan Walisongo, Vol. 20, (Mei, 2012), h. 10.

${ }^{8}$ Tahsin Alam Robithoh, "Peranan Guru Pendidikan Agama Islam Dalam Menangkal Bahaya Terorisme “, (Skripsi, Jurusan Pendidikan Agama Islam, Fakultas Ilmu Tarbiyah Dan Keguruan, Universitas Islam Negeri Syarif Hidayatullah, Jakarta, 2013), h. 5. 9al-Quran, 4: 29-30.
} 
Dalam kegiatan observasi peneliti bisa membawa check list, rating scale, atau catatan berkala sebagai instrumen observasi. Sehingga dalam kegiatan observasi ada pencatatan melalui chek list yang telah disusun peneliti. Pengamatan dapat dilakukan dalam situasi dan objek asli (alamiah) atau pada objek buatan (by design). Dilihat dari cara melakukannya, ada dua macam observasi, yaitu observasi langsung dan observasi tidak langsung. Observasi langsung adalah kegiatan pengamatan yang dilakukan oleh peneliti dalam kancah atau objek penelitian secara langsung. Peneliti bisa melakukan interaksi visual dengan objek yang diteliti. Sedangkan observasi tidak langsung adalah pengamatan yang dilakukan peneliti dengan menggunakan alat bantu, baik elektronik maupun manusia. Secara teknis, peneliti dapat menggunakan alat bantu perekam gambar untuk melakukan observasi tidak langsung.

Teknik observasi ini menjadi teknik pengumpulan data utama untuk penelitian yang target datanya berupa tingkah laku atau interaksi. Teknik observasi dibagi menjadi dua, yaitu observasi terbuka dan observasi tertutup. Observasi terbuka adalah pengamatan yang dilakukan peneliti dan diketahui oleh orang yang diamati. Model observasi seperti ini disebut juga observasi partisipatif, peneliti melakukan interaksi dengan orang yang diteliti. Sedangkan observasi tertutup adalah pengamatan yang dilakukan peneliti dimana orang yang diteliti tahu kalau sedang diobservasi. Peneliti menjaga jarak dan tidak melakukan interaksi dengan yang diamati.

Pada teknik wawancara peneliti mengumpulkan data dengan mengajukan pertanyaan secara langsung kepada informan dan jawaban-jawaban informan dicatat atau direkam dengan alat perekam. Wawancara juga bisa dikatakan sebagai proses komunikasi atau interaksi untuk mengumpulkan informasi dengan cara tanya jawab antara peneliti dengan informan atau subjek penelitian. Dengan kemajuan teknologi informasi seperti saat ini, wawancara bisa saja dilakukan tanpa tatap muka, yakni melalui media telekomunikasi. Pada hakikatnya wawancara merupakan kegiatan untuk memperoleh informasi secara mendalam tentang sebuah isu atau tema yang diangkat dalam penelitian. Atau, merupakan proses pembuktian terhadap informasi atau keterangan yang telah diperoleh lewat teknik yang lain sebelumnya.

Teknik dokumentasi sengaja digunakan dalam penelitian ini, sebab: Pertama, sumber ini selalu tersedia dan murah terutama ditinjau dari waktu; Kedua, merupakan sumber informasi yang stabil, baik keakuratannya dalam merefleksikan situasi yang terjadi dimasa lampau, maupun dapat dan dianalisis kembali tanpa mengalami perubahan; Ketiga, rekaman dan dokumen merupakan sumber informasi yang kaya, secara kontekstual relevan dan mendasar dalam konteksnya; Keempat, sumber ini sering merupakan pernyataan legal yang dapat memenuhi akuntabilitas. Hasil pengumpulan data melalui cara dokumentasi ini, dicatat dalam format rekaman dokumentasi. Dalam hal ini penulis berusaha menggali data melalui dokumen, baik berupa catatan harian, dokumentasi hasil wawancara, gambar dan lain-lain.

Setelah semua data terkumpul, maka data tersebut perlu untuk di analisis. Analisis yang dilakukan berupa mengidentifikasi data, menyeleksi, dan selanjutnya dilakukan klasifikasi data, serta menyusun data. Diharapkan dari pengelolaan data 
tersebut dapat diperoleh gambaran yang akurat dan konkrit dari subjek penelitian. Adapun tekniknya adalah :

Petama, Editing; tahap ini dilakukan untuk meneliti kembali data-data yang telah diperoleh terutama dari kelengkapannya, kejelasan makna, kesesuaian serta relevansinya dengan tujuan apakah data-data tersebut sudah mencukupi untuk memecahkan permasalahan yang diteliti serta untuk meningkatkan kualitas data. Dalam penelitian ini editing digunakan untuk mengoreksi, menambah atau mengurangi kata-kata dari hasil wawancara peneliti terhadap informan yang sekiranya tidak sesuai. Kedua, Verifying; verifikasi data adalah pembuktian kebenaran data untuk menjamin validitas data yang telah terkumpul. Verifikasi ini dilakukan dengan cara menemui sumber data (informan) dan memberikan hasil wawancara dengannya untuk ditanggapi apakah data tersebut sesuai dengan yang di informasikan olehnya atau tidak. Dan ketiga, analizyng; yang dimaksud dengan analyzing disini adalah proses penyederhanaan kata ke dalam bentuk yang lebih mudah dibaca dan juga mudah untuk diinterpretasikan.

Penelitian ini dilakukan di Pondok Pesantren Al Ma'ruf Kota Kediri yang berlokasi di Dusun Kedunglo, Kelurahan Bandar Lor, Kecamatan Mojoroto, Kota Kediri, Jawa Timur. Kata “Al Ma'ruf” tafaulan dengan muasis Pondok Pesantren Kedunglo. Letak geografis Pondok Pesantren Al Ma'ruf sangat strategis sekali dengan pusat pemerintahan, perdagangan dan pendidikan. Hanya berjarak kurang lebih $3 \mathrm{Km}$ dengan pusat pemerintahan Kota Kediri, dan berjarak kurang lebih $2 \mathrm{Km}$ dengan pusat perdagangan dan pendidikan, menjadikan posisi Pondok Pesantren Al Ma'ruf sangat mudah dikenali dan dijangkau.

\section{Pembahasan}

Membicarakan tentang radikalisme hingga saat ini masih menjadi perdebatan yang hangat. Sebagian berpendapat bahwa radikalisme hanyalah bagian strategi politik para kelompok agamis. Sebagian lainnya menyataka bahwa radikalisme didukung oleh doktrin agama. Jika kita melihat kembali sejarah awal munculnya radikalisme agama dalam sejarah Islam telah tampak benih-benihnya pasca wafatnya Nabi Muhammad SAW pada masa Khalifah Utsman bin Affan yang dilatar belakangi ketidak percayaan sebagian kelompok Islam pada masa itu. Lalu munculah kaum Khawarij yang pada saat itu menaruh ketidak-percayaan kepada Mu'awiyah maupun Khalifah Ali bin Abi Thalib. Khawarij sendiri mempropagandakan dan menyikapi perbedaan dengan cara kekerasan hingga mengkafirkan. Kelompok khawarij sendiri merupakan kelompok yang keluar dan memisahkan diri dari barisan Sayyidina Ali bin Abi Thalib. Khawarij yang dipimpin Mu'awwiyah bin Abi Sufyan tidak setuju dengan keputusan yang dikeluarkan oleh Sayyidina Ali dan lalu memusuhi hingga memerangi. Pada akhirnya kelompok khawarij merencanakan pembunuhan kepada Sayyidina Ali bin Abi Thalib, dan berhasil dilakukan pada saat melakukan shalat shubuh.

Dari pemaparan diatas inilah yang menjadi hal yang sangat memperlihatkan perbedaan dengan ajaran Islam yang sebenarnya. Islam yang mengajarkan kedamaian, keselamatan dan kesejahteraan pada sesama, bukan dengan tindakan-tindakan kekerasan. Dalam hal ini, pondok pesantren berperan penting untuk meluruskan pemahaman- 
pemahaman agar Islam dikenal dengan lemah lembut, bukan dengan tindakan radikalis seperti kekerasan, teror dan sebagainya. Oleh karena itu perlu adanya strategi dalam menerapkan pencegahan terhadap paham radikalisme agama di Pondok Pesantren Al Ma'ruf Kediri dengan menekankan karakter religius.

Dari hasil wawancara yang dilakukan, ada 4 strategi pondok pesantren dalam mencegah paham radikalisme agama di Pondok Pesantren Al Ma'ruf Kediri, diantaranya:

a. Strategi Pembelajaran

Berdasarkan hasil dari wawancara dan observasi yang peneliti lakukan, pembelajaran merupakan hal yang paling utama untuk menumbuhkan nilai-nilai karakter peserta didik agar peserta didik memiliki nilai-nilai karakter kejujuran, kedisiplinan, rasa tanggung jawab dan lain-lain yang bertujuan untuk mencegah paham radikalisme agama terhadap para santri di Pondok Pesantren Al Ma'ruf Kediri.

Untuk menumbuhkan di dalam diri para santri, penyampaiannya harus dalam suasana kondusif dan dalam kehidupan sehari-hari di pondok pesantren. Para tenaga pengajar dan pengurus pondok pesantren harus menjadi teladan bagi para santri. Selain itu agar pelaksanaannya sesuai dengan yang diharapkan, tenaga pengajar harus memperoleh pengetahuan dan pemahaman tentang konsep budi pekerti, strategi pelaksanaan, dan sistem penilaiannya. Menurut Law Kohbegr, setidaknya hal demikian dapat menjadi acuan untuk menyamakan persepsi dalam mengelola pendidikan budi pekerti. ${ }^{10}$

Law Kohbegr membagi pemikiran moral menjadi 6 bagian, yaitu :

1) Orientasi hadiah dan hukuman, dengan sasaran anak mulai usia 3 tahun.

2) Orientasi relativitas instrumental, yang menunjukkan dominasi kepentingan dalam kesenangan diri.

3) Orientasi anak manis, yang menggambarkan perilaku anak untuk menyenangkan lingkungan mereka.

4) Orientasi aturan dan ketertiban, yang menunjukkan penghargaan terhadap ketertiban sosial.

5) Kontrak sosial dan hak individu, yang menyatakan kepatuhan terhadap hak dan prosedurnya.

6) Etika universal, yang berdasarkan atas hati nurani. ${ }^{11}$

b. Strategi Keteladanan

Keteladanan merupakan metode yang efektif dan efisien, karena peserta didik pada umumnya dan para santri khususnya cenderung meneladani (mencontoh) guru atau pendidiknya, strategi keteladanan ini dapat dilakukan setiap saat dan sepanjang waktu, strategi ini merupakan metode termurah dan tidak memerlukan tempat tertentu seperti menerapkan pembelajaran. Hal ini sesuai dengan penuturan kepala pondok pesantren Al Ma'ruf yang menyatakan bahwa:

10 Masnur Muslich, Pendidikan Karakter Menjawab Tantangan Krisis Multidimensional cet. 4, (Jakarta: Bumi Aksara, 2014), h. 178

${ }^{11}$ Mansur Muslich, h. 179

Tribakti: Jurnal Pemikiran Keislaman

Volume 30, Nomor 2, Juli 2019 
Strategi keteladanan pada dasarnya strategi yang sangat murah, mudah dan sangat efektif diterapkan, namun yang terjadi pada saat ini meskipun guru telah melakukan keteladanan pada santri, dari pihak santri kurang merespon dari upaya yang dilakukan. Dari permasalahan ini kami sebagai pihak pesantren mengambil inisiatif selain strategi keteladanan harus ada pembinaan. Dalam artian pihal pesantren tetap menerapkan metode keteladanan namun juga perlu didukung dengan pembinaan. Metode keteladanan ini diterapkan terutama pada masalah kedisiplinan, peduli baik dengan teman maupun lingkungan. ${ }^{12}$

Keteladanan lebih mengedepankan pada aspek perilaku dalam membentuk tindakan nyata dari pada sekedar berbicara tanpa aksi. Faktor penting dalam mendidik adalah terletak pada keteladanan yang bersifat multidimensi, yakni ketekatan dalam berbagai aspek kehidupan, keteladanan bukan hanya sekedar memberi contoh dalam melakukan sesuatu, tetapi juga menyangkut beberapa hal yang dapat diteladani, termasuk kebiasaan-kebiasaan yang baik merupakan contoh bentuk keteladanan. ${ }^{13}$

Pribadi tenaga pengajar memiliki andil yang sangat besar terhadap keberhasilan pendidikan, terutama dalam pembentukan karakter yang sangat berperan dalam menumbuhkan karakter Islam peserta didik. Keteladanan ini memiliki peran dan fungsi yang sangat penting dalam menumbuhkan karakter guna menyiapkan dan mengembangkan sumber daya manusia, serta mensejahterakan masyarakat, kemajuan negara dan bangsa pada umumnya.

c. Strategi Pembinaan

Pembinaan di pondok pesantren sangat diperlukan sehingga para santri dapat bersikap dan bertingkah laku sesuai dengan norma-norma, etika, dan kesusilaan yang ada dalam masyarakat. Melalui pembinaan di pondok pesantren Al Ma'ruf, para santri dibina, dibentuk, diarahkan dan dibimbing untuk sifat dan karakter yang baik sehingga dirinya dapat menunjukkan sikap atau perilaku yang baik ketika berkomunikasi dengan orang lain maupun dengan masyarakat lainnya.

Kepala pondok pesantren Al Ma'ruf Kediri menanggapi mengenai pembinaan yang dilakukan di pondok pesantren sebagai berikut:

Pembinaan pada santri sangatlah perlu dilakukan oleh para guru, pengurus maupun para santri di pesantren, karena sebenarnya masalah pembinaan tersebut bukan hanya dititik beratkan kepada guru dan pengurus saja, akan tetapi juga perlu dukungan dari para santri untuk mendukung dan mengikuti pembinaan yang diterapkan di pesantren. Pembinaan dalam menerapkan nilai-nilai pendidikan sangat banyak dilakukan di pondok pesantren Al Ma'ruf. Dalam artian semua kegiatan memang diterapkan secara nyata. Seperti pembinaan melalui madrasah diniyah, sorogan kitab, jam'iyyah dan masih banyak lagi. Namun semua ini tidak terlepas dari kekurangan dan kelemahankelemahan sebab berhasilnya suatu lembaga pendidikan seperti

12 Wawancara, Ahmad Ibnu Mubarok Ketua Pondok Pondok Pesantren Al Ma'ruf, 20 Februari 2019, Kantor Pengurus Pondok Pesantren, 09.00 WIB.

${ }^{13}$ Hidayatullah Furqon, Pendidikan Karakter: Membangun Peradaban Bangsa (Surakarta: Yuma Pusaka, 2010), h. 41. 
pondok pesantren dapat dilihat bagaimana proses pembinaan yang dilakukan di pesantren. Intinya ketika pihak pesantren mendapati santri yang memiliki perilaku yang kurang baik, seperti: membolos ketika kegiatan pesantren berjalan, berkelahi dengan temannya dan lain-lain. Maka, pihak pesantren khususnya pengurus dengan tegas langsung memberikan hukuman yang sesuai dengan pelanggaran yang telah dilakukan. ${ }^{14}$

Dari hasil wawancara tersebut dapat disimpulkan bahwa strategi pembinaan yang diterapkan agar tertanamnya nilai-nilai karakter yang baik pada santri salah satunya adalah dengan adanya pembinaan khusus. Sedangkan pembinaan khusus yang diterapkan di pondok pesantren Al Ma'ruf Kediri adalah mewajibkan seluruh santri untuk mengikuti kegiatan seperti madrasah diniyah, sorogan kitab, jam'iyyah dan masih banyak lagi. Dengan demikian selain nilai karakter religius para santri juga secara tidak langsung menerapkan kegiatan kedisiplinan dan tanggung jawa serta menyalurkan bakat dan minatnya melalui kegiatan tersebut, terlebih pada kegiatan jam'iyyah.

d. Strategi Pembiasaan

Pembiasaan adalah sesuatu yang sengaja dilakukan secara berulang-ulang agar sesuatu itu dapat menjadi kebiasaan. Pembiasaan sebenarnya berintikan pengalaman, yang dibiasakan itu adalah sesuatu yang diamalkan. Dalam psikologi pendidikan pembiasaan dikenal dengan istilah operan condirioning, teori ini mengajarkan peserta didik untuk membiasakan perilaku terpuji, disiplin, giat belajar, bekerja keras, ikhlas, jujur dan berani bertanggung jawab atas setiap tugas yang diberikan. Dalam pelaksanaan pendidikan karakter, pembiasaan peserta didik akan lebih aktif jika ditunjang dengan keteladanan dari tenaga pendidik dan tenaga kependidikan lainnya, oleh karenanya strategi ini dalam pelaksanaannya tidak akan terlepas dari keteladanan dan pembiasaan diarahkan pada upaya pembudayaan aktivitas tertentu sehingga menjadi aktivitas yang terpola atau terorganisir. ${ }^{15}$

Pembiasaan itu perlu diterapkan oleh guru dalam proses menumnuhkan sifat atau karakter yang baik. Pembiasaan akan membangkitkan internalisasi nilai dengan cepat, karena nilai merupakan suatu penetapan kualitas terhadap objek yang menyangkut jenis aspirasi atau minat.

\section{Kesimpulan}

Berdasarkan dari uraian sebelumnya pada dasarnya sangat banyak sekali strategi-strategi suatu lembaga dalam menerapkan pencegahan paham radikalisme agama di pondok pesantren Al Ma'ruf, namun dari banyaknya strategi tersebut pondok pesantren Al Ma'ruf memilih empat strategi yang dianggap tepat untuk menerapkan pencegahan radikalisme agama.

${ }^{14}$ Wawancara, Ahmad Ibnu Mubarok Ketua Pondok Pondok Pesantren Al Ma'ruf, 20 Februari 2019, Kantor Pengurus Pondok Pesantren, 09.00 WIB.

${ }^{15}$ Hidayatullah Furqon, h. 52.

Tribakti: Jurnal Pemikiran Keislaman

Volume 30, Nomor 2, Juli 2019 
Setidaknya terdapat 3 strategi penting yang diterapkan oleh pesantren al Ma'ruf Kediri, yaitu; pertama, melalui keteladanan, strategi ini memberikan tindakan contoh terhadap para santri agar para santri dapat mengikutinya. Keteladanan merupakan metode yang efektif dan efisien, karena peserta didik pada umumnya dan para santri khususnya cenderung meneladani (mencontoh) guru atau pendidiknya, strategi keteladanan ini dapat dilakukan setiap saat dan sepanjang waktu, strategi ini merupakan metode termurah dan tidak memerlukan tempat tertentu seperti menerapkan pembelajaran. Kedua, melalui pembinaan, strategi ini dilakukan dengan membina atau membimbing santri, baik dalam keadaan proses belajar mengajar maupun diluar pembelajaran. Melalui pembinaan di pondok pesantren Al Ma'ruf, para santri dibina, dibentuk, diarahkan dan dibimbing untuk sifat dan karakter yang baik sehingga dirinya dapat menunjukkan sikap atau perilaku yang baik ketika berkomunikasi dengan orang lain maupun dengan masyarakat lainnya. Dan ketiga, melalui pembiasaan, pembiasaan dilakukan dalam penerapan pembiasaan terhadap para santri berdasarkan peraturan tertulis ataupun tidak. Pembiasaan adalah sesuatu yang sengaja dilakukan secara berulang-ulang agar sesuatu itu dapat menjadi kebiasaan. Pembiasaan sebenarnya berintikan pengalaman, yang dibiasakan itu adalah sesuatu yang diamalkan.

\section{Daftar Pustaka}

Departemen Agama RI, al-Quran dan terjemahnya. Jakarta: Maghfiroh Pustaka, 2006

Forum Kajian Ilmiah AFKAR, Kritik Ideologi Radikal: Deradikalisme Doktrin Keagamaan Ekstrem Dalam Upaya Meneguhkan Islam Berwawasan Kebangsaan. Lirboyo Press, 2018.

Furqon, Hidayatullah. Pendidikan Karakter: Membangun Peradaban Bangsa Surakarta: Yuma Pusaka, 2010.

Hikam, Muhammad A.S. Deradikalisme: Peran Masyarakat Sipil Indonesia Membendung Radikalisme. Jakarta: Kompas, 2016.

Ismail, Roni. "Islam Dan Damai (Kajian Atas Pluralisme Agama Dalam Islam), Jurnal Religi, Vol. 9, No. 1, Januari, 2013.

Munip, Abdul. “(Menangkal Radikalisme Agama di Sekolah)”, Jurnal Pendidikan Islam, Vol. I, No. 2, 2012.

Muslich, Masnur. Pendidikan Karakter Menjawab Tantangan Krisis Multidimensional. Jakarta: Bumi Aksara, 2014.

Zuhairi, Misrawi. Pandangan Muslim Moderat: Toleransi, Terorisme, dan Oase Perdamaian Jakarta: PT. Kompas Media Nusantara, 2010.

Robithoh, Tahsin Alam. "Peranan Guru Pendidikan Agama Islam Dalam Menangkal Bahaya Terorisme “, Skripsi, Jurusan Pendidikan Agama Islam, Fakultas Ilmu 
Tarbiyah Dan Keguruan, Universitas Islam Negeri Syarif Hidayatullah, Jakarta, 2013

Rokhmad, Abu. "Radikalisme Islam dan Upaya Deradikalisme Paham Radikal", Jurnal Kependidikan Walisongo, Vol. 20, 2012.

SB. Agus. Merintis Jalan Mencegaah Terorisme Jakarta: Semarak lautan Warna Press, 2014.

Wawancara, Ahmad Ibnu Mubarok Ketua Pondok Pondok Pesantren Al Ma'ruf, 20 Februari 2019, Kantor Pengurus Pondok Pesantren, 09.00 WIB. 